\title{
THE EFFECT OF LEARNING METHODS ON COGNITIVE CAPABILITY OF SCIENCE CONCEPT IN EARLY CHILDREN EDUCATION AMBON CITY
}

\author{
Hermelina Abarua* and Rosmaryn Tutupary \\ Faculty of Teacher Training and Educational Sciences, Pattimura University \\ Maluku, Indonesia \\ *email: emiassor@gmail.com
}

\begin{abstract}
This study aims (1) Knowing cognitive abilities in early childhood science concepts taught by experimental methods in Ambon City PAUD (2) Knowing cognitive abilities in early childhood science concepts taught by demonstration methods in Ambon City PAUD (3) Test the significant difference in effect between the use of experimental and demonstration methods on cognitive abilities of early childhood science concepts in Ambon City PAUD. The research was carried out at KB Mawar FKIP Unpatti and TK Ambon Training Advisors. The method used is a quasi-experimental design with pretest-posttest control group design. The population of this research is all students of KB Mawar FKIP Unpatti and TK Kindergarten Ambon Training. Sampling of this study was carried out using proportional random sampling technique which was carried out randomly in 2 classes, namely 20 people. Data was collected through an instrument of observation of the cognitive abilities of scientific concepts. The reliability of achievement motivation instruments is 0.89 , the learning achievement test is 0.90 . Data from this study were processed using the $t$ test analysis technique for independent samples at a significance level of $\alpha=$ 0.05. This research concludes that First. The experimental group children in KB Mawar have the cognitive ability of science concepts using the experimental method showing very good activity with the lowest score of 28 and the highest score of 40 obtained an average price of 35.4 with a Median of 35.5 and Mode of 35. Second. Control group children have the cognitive ability of science concepts using the demonstration method shows that activities develop well with the lowest score of 24 and the highest score of 38 obtained an average price of 30.4 with a median of 30.5 and a mode of 31 . Third. 3. There are differences in the average cognitive ability of science concepts of children aged 5-6 years between students taught by the experimental method and students taught by the demonstration method with the price of tcount $=2.78$ while the table of degrees of freedom $n_{1}+n_{2}-2=18$ at the significance level $\alpha=0.05,1,73$, then $t>t$ table, this means that the difference in the two means is significant at the 0.05 level. It can be concluded that there are differences in the average cognitive abilities of early childhood science concepts in the experimental and control groups. Thus it can be concluded that there is an effect of learning methods on the cognitive abilities of scientific concepts of children aged 5-6 years in Ambon City PAUD
\end{abstract}

Keywords: Experimental Method, Demonstration Method, Cognitive Ability, Science Concept

\section{Introduction}

Organizing early childhood education focuses on growth and development both physically motoric, cognitive, social emotional language and spiritual (moral). How to provide early childhood stimulation is to provide or create activities that cover various aspects of child development by providing various facilities and media needed by early childhood in accordance with their needs. Similarly, for the improvement of children's cognitive abilities. Individuals think using their minds, cognitive behaviors that involve cognitive abilities in the concept of arithmetic begin to be easy to understand as a basis for future mathematics learning. The basic concept of science is to recognize the concept of numbers in group B in the Kindergarten education unit. Efforts to help physical and spiritual growth and development so that children have the readiness to enter further 
education it is necessary to introduce "Science Experiments" which is the study of basic scientific facts in everyday life. The fundamental purpose of science is to develop literate individuals against the scope of science itself, and be able to use its fundamental aspects in solving the problems it faces.

Early childhood can be introduced to nature, play through learning and care for the real environment. Children will learn experiments to explore and investigate the surrounding environment, so as to be able to build an attitude, a deep impression that will be carried and used in adulthood. In practice in early childhood basic education in the city of Ambon, development is still needed through innovative methods. The experimental method and the demonstration method are the methods used while playing in kindergarten, which are rarely applied due to incomplete playing facilities and monotonous teaching systems and the lack of teacher creativity in introducing and utilizing existing learning resources. Thus it is necessary to conduct research on the effect of the experimental and demonstration methods on cognitive abilities of early childhood in Ambon City. The reasons for the selection of this title are: (1) PAUD children have the ability to solve the problems they face through the use of experimental methods and demonstration methods so that children are skilled in solving various things that they face. (2) Children get better scientific knowledge and information and can trusted, it means that the information obtained by children is based on proper scientific standards, because the information presented is objective findings and formulations and in accordance with scientific principles that shelter them. (3) PAUD children are more interested and interested in experiencing activities carried out through experimental methods and demonstration methods carried out in the surrounding environment.

According to Whiterington (1979) in Buchori (1985), play has the function of facilitating the development of children's cognition and allowing children to see the environment, learn something and solve problems they face. Besides that playing can also improve children's development in social, linguistic, motor physical aspects and the development of children's moral values.

Many benefits can be obtained if children from an early age have been introduced to a variety of knowledge so that the learning methods carried out by the teacher are expected to simulate the child so that the knowledge obtained can develop as expected. Experimentation methods and demonstration methods can have an effect because children are given the opportunity to find out for themselves what the teacher gives in accordance with the learning steps and material provided in play activities, familiarize children to follow the stages of experimentation and demonstration, train children to be careful because children must observe, make predictions and make decisions.

Based on observations on January 10, 2019 conducted in one of the Kindergartens in Ambon City, namely the Ambon Kindergarten Development Trainers and the Ambon FKIP Unpatti Rose Play Group about the use of the Experiment Method and Demonstration Method, several problems were encountered: (1) Some large student development is below standard with mastery learning reaching two stars or just beginning to develop. It is expected that the child is said to develop is to reach four stars or develop very well, (2) The method used is a method of play that only involves children playing without the teacher paying attention to cognitive development children, (3) Have not been able to foster a pleasant learning atmosphere in the sense that most students have not been active in the learning process in class. This is reinforced by Whiterington (1979) in Buchori (1985) play has the function of facilitating the development of children's cognition and allows children to see the environment and can solve problems faced.

Related to the above problems, it is necessary to try and implement innovative learning methods in order to help the teacher to develop children's scientific abilities in thinking and skilled in solving problems, making experiments and demonstrating activities according to the teacher's instructions in the classroom and outside the 
classroom. Starting from the background of the problem above, the research problem can be formulated as follows: (1) How are cognitive abilities in early childhood science concepts taught by experimental methods in Ambon City PAUD? (2) How are cognitive abilities in early childhood science concepts? taught by the demonstration method in Ambon City PAUD? (3) Is there a difference in the effect of the use of the experimental method and the demonstration method on the cognitive development of early childhood science concepts in Ambon City PAUD? with the aim of: (1) Knowing cognitive abilities in early childhood science concepts taught by experimental methods in Ambon City PAUD, (2) Knowing cognitive abilities in early childhood science concepts taught by demonstration methods in Ambon City PAUD, (3) Test the significant difference between the use of experimental and demonstration methods on cognitive abilities of early childhood science concepts in Ambon City PAUD

\section{Cognitive Definition}

Cognitive is one aspect of human development related to knowledge, namely all psychological processes related to how individuals learn and think about their environment (Desmita, 2012). This is in line with the opinion of Myers (in Desmita, 2012) that cognitive is all mental activities associated with thinking, knowledge and memory. This was also stated by the Web (in Holis, 2016) that cognitive is a process of knowing. Piaget (in Mukhlisah, 2015), cognitive is how children adapt and interpret objects and events around them. Kwartolo (2007) also explains that human cognitive is determined from within human beings themselves. Vygostky (in Moeslichateon, 2004) cognitive is the ability to pay attention, observe, remember and reasoning that involves learning using community findings such as language, mathematical systems and memory tools. This is in accordance with Kwartolo (2007) which states that humans not only develop in the biological social sense, but psychological functions such as perception, attention, memory that continue to increase from birth. This is because humans are transformed in social and educational contexts through language, means, and culture, human social laws continue to develop until they reach a higher level of cognitive psychology.

Based on some of the statements above, it can be concluded that cognitive is a mental activity associated with perception, attention, memory, language, culture and information processing that are interrelated with knowledge, memory and thought processes as well as all psychological processes related to learning, paying attention, observing, imagine, judge and think about the environment.

Basic Concepts of PAUD Science.

Science is an object of discussion that is related to the field of study of reality or facts and is accompanied by theories that explain natural phenomena. There are several divisions of branches in science namely Biology, Physics, Chemistry and Earth Sciences. Each branch is divided into several more specific sections. Zoology and botany are part of the branch of biology. The scope of the science learning program will be developed into three basic substances namely education and science learning containing programs that facilitate the mastery of the science process, the mastery of science products and programs that include the development of scientific attitudes.

The introduction, understanding and love of science must start early, if we want our generation to be no less competitive with young people abroad. Every child can benefit from various scientific events and try to analyze them, such as collecting various kinds of leaves, rocks, shells, catching boolas, reading about types of animals and so on. As educators, we must first understand and realize science as a very useful and exclusive activity (only belonging to scientists).

One of the basic skills development in PAUD is cognitive ability. Cognitive abilities are needed by children to develop knowledge about what is seen, heard, felt, touched and 
smelled through their five senses. Cognitive is a thought process where individuals have the ability to connect, judge and consider an event or event (Sujiono, 2010). The experimental method is one of the appropriate learning methods for learning science. In everyday activities, children will be dealing with the world of science starting from simple to those that require complex thinking.

Science is a part of our lives, and our lives are an important part of learning science. One of the main characteristics of learning science in early childhood is the interaction between children and the environment, this is because science education is the same as other education which has an important role in shaping the personality and intellectual of children.

Children must be given the opportunity to be in direct contact with the object to be or is being learned. With learning activities like this the child is learning about what is called science. Children are guided to search for problems, look for various explanations about the phenomena and events they see, develop physical motoric and practice using their reasoning to solve and find solutions to problems encountered by conducting relevant experiments. Science for early childhood has a component that is science is a product, and science as a process. As a product, science is a well-organized body of knowledge about natural physics. As a process, science involves experimenting, tracking and observing. This is very important, because children can participate in the scientific process so that the skills they get will be taken to other developments and be beneficial to children's lives.

Through science learning can train the ability to think. If the child's thinking ability develops; then the child can process the acquisition of his learning, find various kinds of alternative problem solving and develop mathematical logic skills. In addition, children also have the ability to be able to sort out, classify and prepare the development of thinking skills. This is in accordance with the opinion of Wahid \& Suyanto (2015) that introducing science from an early age means helping children to start thinking critically and logically. Science helps children experiment, explore, and observe the surrounding environment. This is slowly able to build children's character to get used to thinking scientifically, trained to solve problems, and have high analysis.

According to Yulianti (2010), there are several types of science skills that can be trained in early childhood. First, observing the child is invited to observe the phenomenon or natural events that occur in the environment around the child itself, starting from the simplest things. Second, classifying the child is asked to classify objects according to their categories. Third, estimating, namely the child is asked to predict what will happen. Fourth, counting, namely the child is encouraged to count the objects that are around then introduce the forms of objects to the child.

Based on some of these things, there are several scientific concepts that children can learn, including recognizing surrounding objects according to size (measurements), objects put in water (floating or sinking), trying and distinguishing various kinds of taste, smell and sound; color mixing and plant growth process.

Piaget (in Gunarti, Suryani and Muis, 2008) in providing science learning to young children, especially the provision of science and mathematics must be concrete (real) and active. Concrete thinking is realistic thinking according to the knowledge received by the five senses. Being active means investigating problems and placing them in possible solutions, looking for cause-effect relationships, recording results from various experiments and being able to make generalizations. 


\section{Research Methods}

\section{a. Definition of Experimental Method}

Enggen (2012), defines the method of expression as a way of presenting subject matter in which the child actively experiences and proves himself about what he is learning. Through this method, children are totally involved in doing themselves, following a process, following an object, analyzing, proving and drawing their own conclusions about an object, situation or process. Djamarah (2000) argues that the experimental method is a method of providing opportunities for individual early childhood or groups, with the aim of being trained to carry out a process and an experiment. It was also added by Winataputra (2005) that the experimental method is a teaching method in the presentation or addition of material through the results of experiments or individuals trying something accompanied by the process of observing the process. Nugroho (2008) describes the experimental method as a method which provides an opportunity for children to practice conducting direct evidence by conducting experiments, observing the experimental process and finding conclusions about events in the research process. With the experiment the child will not simply take the amount of information obtained, but try to manage its acquisition by comparing the stages of facts obtained in the experiments conducted.

Based on the descriptions above, it can be concluded that the experimental method is a method or method of presentation in which the child actively explores, seeks and discovers what he is learning. This is obtained through a process of experimentation and observing what the individual does, to compare the stages of the facts he obtained.

\section{b. Demonstration Method}

The demonstration method is a teaching method by demonstrating goods, events, rules and sequences of conducting activities, both directly and through the use of media that are relevant to the subject matter or material presented (Shah in Susanto, 2017). Demonstration method is a form of presentation of learning activities with oral explanations accompanied by actions and shows a process or way of working an object with respect to learning material (Djamarah, 2000). With the demonstration method in front of the class will be able to provide experiences and impressions from the learning performance of an event or phenomenon, with the aim that students can find concepts through an integrated concentration of students and teachers. Students feel the results of the demonstration method that is getting a pleasant learning experience by optimizing student learning styles (Shah, 2000).

\section{c. Research design}

This study uses a quasi-experimental research design, with a pretest-posttest control group design (Wiersma, 1995: 139, Tuckman 1999). This quasi-experimental research design uses class (intact group). So quasi-experimental research uses all subjects in the learning group (intact group) to be treated (treatment), and not using subjects taken at random. Thus the design used in this study is Pretest-Posttest Control group Design.

The subjects in this study were PAUD Mawar FKIP Unpatti and Kindergarten Exercise, the subjects of this study were students of PAUD Mawar FKIP Unpatti in the age group of 5-6 years totaling 10 people who were used as the experimental class and Kindergarten Exercise in the 5-6 year age group totaling 10 people serve as the control class. While this research variable consists of: one independent variable (independent variable), one dependent variable (dependent variable), two moderator variables. The independent variable in this study is a learning method that has two namely: the 
experimental method, and the demonstration method. The dependent variable observed as a result of the influence of the independent variable is cognitive ability. Cognitive abilities in this study are scientific abilities that can be seen from observations.

The instrument used in order to solve the problem to be studied or achieve research objectives, in the form of guidelines for assessment or observation that was previously tested given the purpose of this study, which is to reveal the differences in the average ability of early childhood science, then the data analysis technique used is an inferential analysis using the $t$ test. To obtain accurate data, all instruments used were tested on similar schools that had the same character. The results of the trial of the instrument showed that the reliability and validity coefficient of the scientific ability assessment guidelines were 0.89 and 0.87 . For the purposes of analyzing the research data two types of analysis techniques are used, namely: (1) Descriptive analysis, and (2) Inferential analysis.

\section{Results and Discussion}

The results of descriptive analysis of the Science Concept Cognitive Ability score in the experimental group ranged the theoretical score by 10 - 40 and obtained the argument score range with the lowest score of 28 and the highest score of 40 obtained an average price of 35.4 with a Median of 35.5 and Mode of 35, where the distribution of ability scores is between $34-36,3$ people (30\%) who get above the average of 7 people (70\%) and those who score below the average of 3 people (30\%). From these results it shows that the frequency distribution of the Cognitive Ability of the Concept of Early Childhood Science in the experimental group was in the good category.

Based on trial data for the cognitive ability score of the concept of control group theoretical score range of $10-40$ and obtained an argument score range with the lowest score of 24 and the highest score of 38 obtained an average price of 30.4 with a median of 30.5 and a mode of 31 , where the distribution of science ability scores after using the demonstration method is that most of the early childhood ie 3 people $(30 \%)$ have the cognitive ability of science concepts at a score of $30-32$ or are at an average value and above average, whereas almost a portion is above the average score of $30-32$. From these results indicate that the frequency distribution of cognitive abilities data concept of treatment science is included in both categories.

The results of inferential data analysis as stated in chapter III, that the analysis used in hypothesis testing is the $t$ test analysis if the data of both groups are normally distributed and homogeneous. For this reason it is necessary to conduct a data normality test with Liliefors analysis techniques and Homogeneity test with a Barlett test. (Ruseffendi, 1998: 291-297). For normality test using liliefors analysis technique, the L0 value is smaller than $\mathrm{Lt}$, that is in the experimental group $0.1210<0.258$ and the control group is $0.1398<0.258$. Homogeneity testing is done by the Barlett test (Ruseffendi, 1998: 297). This requirement is pleased with the similarity of variance between group data in the experimental group and the control group. Based on the test results for the two groups of data in the experimental group and the control group turned out to be "homogeneous" because the results obtained $\chi^{2}$ count smaller than $\chi^{2}$ tables that is 0.02 $<3.84$.

Hypothesis test results "There are differences in the average Cognitive Ability of Early Childhood Science Concepts in the experimental group with the Cognitive Ability of Early Childhood Science Concepts in the control group with the formulation of statistical hypotheses: $\mathrm{H} 0: \mu_{1}=\mu_{2}, \mathrm{H}_{1}: \mu_{1}>\mu_{2}$ Analysis of differences between Abilities Cognitive Concepts of Early Childhood Science in the experimental group (X1) with Cognitive Ability of Early Childhood Science Concepts in the control experimental group (X2) use analysis $\mathrm{T}$ test for independent samples from two different groups to find out 
whether the research hypothesis can be accepted or rejected. From the calculation results obtained $t_{\text {count }}=2.78$ while $t_{\text {table }}$ with degrees of freedom $n_{1}+n_{2}-2=18$ at the significance level $\alpha=0.05$ obtained 1,73 then $t_{\text {count }}>t_{\text {table }}$, this means that the difference in both means is significant at the 0.05 level. Thus it can be concluded that there are differences in the average cognitive abilities of early childhood science concepts in the experimental group and the control group. This proves that the effect of the experimental method on the development of cognitive abilities of early childhood science concepts so that the use of this method is highly recommended for educators so that in planning and implementing the learning process can use and apply experimental methods to develop various aspects of development. The use of the experimental method implies that in its use as a method it always provides opportunities for children to practice conducting direct evidence by conducting experiments, observing the experimental process and finding conclusions about events in the research process, the cognitive abilities of science concepts because science is part of our lives, and our lives an important part of science learning. One of the main characteristics of learning science in early childhood is the interaction between children and the environment, this is because science education is the same as other education which has an important role in shaping the personality and intellectual of children. Thus in addition to developing cognitive abilities the concept of science in this case refers to aspects of cognitive development and developing the ability to recognize the environment around the child must be given the opportunity to be in direct contact with the object to be or is being studied. Learning activities like these children are learning about what is called science. Children are guided to search for problems, look for various explanations about the phenomena and events they see, develop physical motoric and practice using their reasoning to solve and find solutions to problems encountered by conducting relevant experiments.

Science for early childhood has a component that is science is a product, and science as a process. As a product, science is a well-organized body of knowledge about natural physics. As a process, science involves experimenting, tracking and observing. This is very important, because children can participate in the scientific process so that the skills they get will be taken to other developments and be beneficial to children's lives. Through science learning can train the ability to think, if the child's thinking ability develops; then the child can process the acquisition of his learning, find various kinds of alternative problem solving and develop mathematical logic skills. In addition, children also have the ability to be able to sort out, classify and prepare the development of thinking skills. This is in accordance with the opinion of Wahid \& Suyanto (2015) that introducing science from an early age means helping children to start thinking critically and logically. Science helps children experiment, explore, and observe the surrounding environment. This is slowly able to build children's character to get used to thinking scientifically, trained to solve problems, and have high analysis. Especially for educators having new experience to improve professionalism in developing various materials and program activities in PAUD institutions and being able to carry out their duties and responsibilities as PAUD educators who are professional.

Based on the explanation above, it can be concluded that there are significant differences in the average cognitive ability of science concepts between the experimental group and the control group through the use of experimental methods. This is because these activities are in accordance with the principles of learning for young children, which contain elements that are familiar to children, simple, learning while playing, using sensory, and learning while doing. Soluble and insoluble material experimentation activities are simple materials for children, and involve children directly to explore with concrete objects. In accordance with the statement of Sofia Hartati (2005: 30) that the principle of learning for young children must be fulfilled in order to achieve optimal developmental stages. Supported by Piaget (Slamet Suyanto, 2005: 128) explains that 
children are in the pre-operational phase, where learning through concrete objects will be better and more meaningful.

The enthusiasm of children directly involved in conducting experiments shows that by being directly involved, children's motivation increases and can measure children's science process skills. Previous research conducted by Nurmaleni (2014) and Djamarah (2000) suggested that the experimental method is a method of giving opportunities to individual children or groups, with the aim of being trained to carry out a process and an experiment. It was also added by Winataputra (2005) that the experimental method is a teaching method in the presentation or addition of material through the results of experiments or individuals try something accompanied by a process of observing the process, it can be concluded that the experimental method is a method or method of presentation where children actively explore, searching and discovering for himself what he learned, this is obtained through a process of experimentation and observing what individuals do, to compare the stages of facts they obtain.

From the explanation of the results of the research that has been described it is known that the teacher has a role in helping children develop scientific concepts through the experimental method and the demonstration method. The teacher's role is to help children find knowledge through experimental activities and demonstrations by providing explanations, information, and questions. With the explanation, information, and questions provided by the teacher can guide children to find answers in their own way. Ali Nugraha (2008: 136-137) explains that in learning science teachers have roles, such as as an initiator, facilitator, observer, elaborator, and motivator. The teacher has the role of opening the children's initiative, creating conducive learning, observing the child's activities, asking stimulating questions, and providing reinforcement. In addition to the teacher's role, the role of peers in groups also helps children develop basic science process skills. Founded by researchers, that in carrying out activities in groups children interact with group friends, conduct discussions, and help friends in difficult groups. Vygotsky (William Crain, 2007: 371) explains the concept of proximal development zones that the level of development is difficult to achieve by children can be achieved with the guidance of adults or in collaboration with more capable colleagues. The child's ability to accept explanations and direction given by the teacher shows that early childhood have high curiosity and easily absorb the information provided. This indicates that the child also has good cognitive.

The researcher also found that in carrying out group activities children interact with group friends, express ideas, conduct discussions, and help friends in difficult groups. Explained by the opinion of Vygotsky (Slamet Suyanto, 2005: 128) that when playing children usually express ideas in words, ask themselves, and answer their own questions or internal speech. In developing the science skills of children's interactions with adults and peers affect the way children think. So in developing science skills for early childhood, the application of cooperative learning that enables brainstorming is highly recommended. Another thing that affects the ability of science is the experience that is brought or already owned by children.

Thus the cognitive ability of science concepts in children aged 5-6 years in Ambon City PAUD is influenced by internal and external factors. Internal factors are factors that originate from within the child, namely the child's cognitive abilities. Cognitive abilities in this study include the ability to solve problems and the ability to think logically. While external factors are factors that originate from outside the child's self include, the implementation of learning, the role of teachers and peers, as well as the child's previous experience. Therefore, the development of the cognitive abilities of scientific concepts by showing exploratory and probing activities, showing creative attitudes in solving problems, compiling plans for activities to be carried out and recognizing cause and effect about their environment which should be carried out through experimental methods and 
group demonstrations using congress objects, and the teacher acts as a facilitator who provides information and direction. However, this study has limited scope which only discusses the concepts of science in soluble and insoluble experimental activities using demonstration and experimental methods. This indicates that there is a need for further research on different themes and topics to further elaborate on the concept of science.

\section{Conclusions}

Overall, early childhood learning scientific concepts using experimental methods and demonstration methods has a very good influence on children's development. In more detail, children in the experimental group namely in KB Mawar have the cognitive ability of scientific concepts using the experimental method showing exploratory and probing activities, showing creative attitudes in solving problems, planning of activities to be carried out, and recognizing cause and effect on their highly developed environment. well Children in the control group have the cognitive ability of science concepts using the demonstration method showing exploratory and probing activities showing creative attitudes in solving problems planning planning activities to be carried out and knowing cause-effect about their well-developed environment.

There is an average difference in the cognitive abilities of scientific concepts of children aged 5-6 years between students taught by the experimental method and students taught by the demonstration method. It can be concluded that there are differences in the average cognitive abilities of early childhood science concepts in the experimental and control groups. Thus, it can be concluded that there is an influence of the experiment method and the demonstration method on the cognitive abilities of science concepts of children aged 5-6 years in PAUD Ambon City.

\section{References}

Desmita. (2012). Developmental psychology. Bandung: PT Youth Rosdakarya Offset

Desmita. (2012). Developmental Psychology of Students. Bandung: PT Rosdakarya Offset

Djamarah, S.B. (2000). Teachers and Students in Educational Interactions. Jakarta: Rineka Cipta

Dimiati and Mudiono (2009) Learning and Learning. Jakarta: Rineka Cipta.

Gunarti, W., Suryani, L., \& Muis, A. (2008). Methods for Developing Early Childhood Behaviors and Abilities. Jakarta: Open University

Hergenhah, B.R., \& Olson. (2008). Theories of Learning. Jakarta: Kencana

Holis, A. (2016). Learning Through Play for the Development of Creativity and Cognitive Early Childhood. Garut University Education Journal Faculty of Islamic Education and Teaching University of Garut, (09) 01, 23-37

Iru, L., \& Arihi, L.O.S. (2012). Analysis of the Application of Learning Approaches, Methods, Strategies and Models. Yogyakarta: Multi Presindo

Kwartolo, Y. (2007). Brilliant Class in Vygotsky's Perspective. Journal of Sower Education, (6) 8, 29-38

Moeslichatoen, R. (2004). Teaching Methods in Kindergarten. Jakarta: PT Asdi Mahasatya 
Mukhlisah, AM. (2015). Jean Piaget's Cognitive Development and Improvement of Dyscalculic Children's Learning (Case Study on MI Diponegoro's MI). Journal of Islamic Education, (6) 02, 118-143

Moeslichatoen, (1987) Teaching Methods in Kindergarten, Publisher, Jakarta: Rineka Cipta

Montolalu, B.E.F. et al, (2010) Playing and Children's Games Jakarta Publisher: Open University.

Rachmawati, Y., \& Kurniawati, E. (2005). Creativity Development Strategies in Kindergarten Children. Jakarta: Ministry of Education and Culture

Sujiono, Y.N. (2009). Basic Concepts of Early Childhood Education. Jakarta: PT Index

Syah, M. (2000). Educational Psychology with a New Approach. Bandung: Teen Rosdakarya

Suarsimin Arikunto (1998),, Research Procedure, Jakarta: Rineka Cipta.

Wahid, S.M.J., \& Suyanto, S. (2015). Improving Science Process Skills through Simple Experiments Children 5-6 years old at TK-IT Albina Ternate. Journal of Education and Community Empowerment, (2) 1, 55-66

Winataputra, U.S. (2005). Teaching and Learning Strategies. Jakarta: Open University.

Yuliani, E. (2005). Developmental Psychology. Phonor: Stain PO Press

Yulianti, D. (2010). Play while studying science in kindergarten 